\title{
Effect of New Generation Chemicals in Changing Host Physiological Traits to Manage Sheath Blight Disease Caused by Rhizoctonia solani Kuhn in Rice
}

\author{
Ashajyothi Mushineni ${ }^{1 *}$, Surajit Khalko², Susmita Jha², \\ P.M. Bhattacharya ${ }^{1}$ and Ayon Roy ${ }^{1}$
}

\author{
${ }^{1}$ Department of Plant Pathology, Indian Agricultural Research Institute, New Delhi, India \\ ${ }^{2}$ Department of Plant Pathology, Uttar Banga Krishi Viswavidyalaya, Cooch Behar, \\ West Bengal, India \\ *Corresponding author
}

\begin{tabular}{|c|c|}
\hline & A B S T R A C T \\
\hline $\begin{array}{l}\text { Canopy temper } \\
\text { Chlorophyll con } \\
\text { Fungicides, } \\
\text { Management, } \\
\text { Rhizoctonia, } \\
\text { Sheath blight. }\end{array}$ & \multirow{4}{*}{$\begin{array}{l}\text { With the changing climate, disease scenario has been rapidly changing in a given } \\
\text { environment. Some of the minor pest and diseases are playing greater role in rice } \\
\text { ecosystem. Sheath blight Sheath blight, under high rainfall areas, is becoming fatal to the } \\
\text { rice production. As there is no true resistance yet been identified for this disease, farmers } \\
\text { are still dependent on chemical management. This study includes In-vivo analysis of seven } \\
\text { new generation chemicals to test their efficacy in altering the host physiological traits in } \\
\text { order to manage sheath blight, the devastative disease of rice caused by Rhizoctonia solani. } \\
\text { Chemical treatment was given twice at } 15 \text { days interval. The significant change in the } \\
\text { physiological traits in terms of increase in chlorophyll content (AUSDC-817) and } \\
\text { reduction in canopy temperature (AUCTPC-575) was observed in treatment plot } \\
\text { Azoxystrobin } 23 \% \text { SC with highest projected yield }(6.9 \mathrm{t} / \text { ha), Benefit Cost ratio and } \\
\text { maximum disease reduction (69.27\%) followed by the Tebuconazole } 50 \%+ \\
\text { Trifloxystrobin } 25 \% \mathrm{WG} \mathrm{with} 6.67 \mathrm{t} / \mathrm{ha} \text { projected yield, } 1: 0.88 \mathrm{BCR} \text { and } 68 \% \text { disease } \\
\text { reduction. }\end{array}$} \\
\hline Article Info & \\
\hline $\begin{array}{l}\text { Accepted: } \\
\text { 04 September } 2017 \\
\text { Available Online: } \\
10 \text { November } 2017\end{array}$ & \\
\hline & \\
\hline
\end{tabular}

\section{Introduction}

To achieve food security for the ever increasing world population the immediate action to be taken is to restrict the pre and post-harvest crop losses. Estimates of global crop losses in rice due to weeds, animal pests, and diseases are $10.2 \%, 15.1 \%$, and $12.2 \%$ of the attainable yield, respectively. A wide range of rice diseases affect rice $(\mathrm{Ou}, 1985)$ among which blast, sheath blight, bacterial blight, brown spot, and several virus diseases, including rice tungro, are of primary concern. An estimation of losses due to sheath blight disease alone in India has been up to $54.3 \%$
(Rajan, 1987; Roy, 1993). The pathogen has a wide host range and can infect all plants belonging to more than 32 plant families and 188 genera (Gangopadyay and Chakrabarti 1982). The available existing literature indicates the disease to be of significant importance and under the changing climatic scenario its seriousness can prove fatal to rice production. It also signifies the need to study the factors both which influences and explains sheath blight resistance and causes of still dependence on chemicals and to find out the best management practices with the available 
resources to reduce the losses. As we know chemicals are harmful for both the environment and human health, it should be kept in mind that research on chemicals which will work at lower doses, leave low chemical foot print in terms of residue and induce resistance in plant system should be encouraged. By keeping all these, this study concentrated on the screening of new generation chemicals In vivo, and studies on their effect in manipulating host physiology to manage disease, to find out the effective chemical control measure against Sheath Blight.

\section{Materials and Methods}

\section{Pathogen isolation}

The test pathogen viz., Rhizoctonia solani causing sheath blight in rice isolated from infected rice sheath and leaf by inoculating on Modified Ko and Hora medium (Ko and Hora 1971, Castro et al., 1988).

The inoculated Petri plates were incubated at $27 \pm 1^{\circ} \mathrm{C}$. The single hyphal tip culture was done to get the pure culture of the pathogen. Rhizoctonia pure culture was maintained on PDA (Riker and Riker, 1936) at $4^{0} \mathrm{C}$ for further use.

\section{Mass culturing and field inoculation}

Fresh rice leaves were chopped into $0.5 \mathrm{~cm}$ $1 \mathrm{~cm}$ pieces and washed twice in sterile distilled water in which antibiotic (Chloramphenicol) was added. The washed leaves were kept in polythene bags and sterilized in autoclave at $121^{\circ} \mathrm{C}, 15 \mathrm{lb}$ psi for 15 minutes. $10 \mathrm{~mm}$ agar disks from actively growing 3 days old fresh Rhizoctonia culture were inoculated in the polybags containing sterilized rice leaf bits. Inoculation was done at 45 days after transplanting. The cultured sclerotia were used for field inoculation. Both the sclerotia and infected leaf bits were inserted in the joint between third leaf sheath and main stem. Two panicles were inoculated in each hill.

\section{In vivo evaluation of chemicals}

The field experiments were carried out at the Instructional farm, Uttar Banga Krishi Viswa vidyalaya, Pundibari, Cooch Behar, West Bengal, India during the kharif season of 2015.Rice cultivar Swarna mashuri (MTU 7029) which is susceptible for sheath blight disease was used and seeds were collected from University Research Farm, UBKV. Seed was treated with Tricyclazole 75\%WP @ $3 \mathrm{~g} / 2 \mathrm{Kg}$ seeds in 3 lit. of water and sown during $1^{\text {st }}$ fortnight of June. 25 days old seedlings were used for transplanting. Two sprays were given at 15 days interval from the initial appearance of the disease in the field. The control plots were sprayed with same volume of water only. Ten hills were selected randomly from the central zone of the each plot of the treatment to avoid border effect. The severity of sheath blight disease was assessed based on the relative lesion height as mentioned in standard evaluation system (SES) for rice and subsequently its corresponding rating value on 0-9 scale given by Anonymous (1996), Percent Disease Index was calculated by using the formula given by the Wheeler (1969) and Area Under Disease Progress Curve was calculated by using Shaner and Finnay (1977) formula as given below:

$$
\operatorname{AUDPC}=\sum_{\mathrm{i}=1}^{\mathrm{n}}\left[\left(\mathrm{X}_{\mathrm{i}+1}+\mathrm{X}_{\mathrm{i})} / 2\right]\left[\mathrm{t}_{\mathrm{i}+1}-\mathrm{t}_{\mathrm{i}}\right]\right.
$$

Where,

$\mathrm{X}_{\mathrm{i}}=$ the proportion of the host tissue damaged<smiles>[121In]</smiles>
at $\mathrm{i}$ day 
$t_{i}=$ the time in days after appearance of the disease at $i^{\text {th }}$ day

$\mathrm{n}=$ the total number of observations

The records of physiological parameters like chlorophyll content leaves and canopy temperature were taken with help of Konica Minolta SPAD meter and Infra-red thermometer respectively, at 7 days interval right from the maximum tillering. Area under Canopy Temperature Progress Curve (AUCTPC) was calculated by using the formula given by the Rosyara (2009).

$$
\left.\operatorname{AUCTPC}=\underset{i=1}{n}\left[\left(X_{\mathbf{i}}+X_{i}+1\right) / 2\right]\left(t_{i}+1-t_{i}\right)\right]
$$

Where,

$\mathrm{x}_{\mathrm{i}}$ is the Canopy Temperature Depression on $\mathrm{i}^{\text {th }}$ date

$t_{i}$ is the $i^{\text {th }}$ day and $n$ is the number of scoring days.

Area Under Spad Decline Curve (AUSDC) was calculated by using the formula given by the Rosyara et al., (2007).

$$
\left.\operatorname{AUSDC}=\sum_{i=1}^{n}\left[\left(X_{i}+X_{i}+1\right) / 2\right]\left(t_{i}+1-t_{i}\right)\right]
$$

Where,

$x i$ is the SPAD value on $i^{\text {th }}$ date

$t_{i}$ is the $i^{\text {th }}$ day and $n$ is the number of scoring days

The grain yield of each plot was recorded after harvesting on net plot basis.

\section{Yield loss assessment}

When $90-95 \%$ grains were riped, panicles were harvested and sun dried for one week.
After threshing, grain weight was recorded for each plot and compared with the control plot to assess the yield loss.

\section{Statistical analysis}

Data was analyzed using statistical package SAS and Indo-stat software. The comparisons were done at 0.05 probability level. Bivariate analysis was done to identify the contribution of physiological traits towards sheath blight disease development, resistance or susceptibility and yield in Rice by taking sheath blight disease score and yield as dependent variable.

\section{Results and Discussion}

All the fungicidal treatments were found to give significantly lower disease severity than control. This is evident from the final observation that lowest diseases severity was obtained in case of Azoxystrobin 23\% SC with a PDI of $15.93 \%$ which is followed by Tebuconazole 50\%+ Trifloxystrobin 25\% WG and Difenconazole 25\% EC with disease severity of 16.67 and $24.44 \%$, respectively. The maximum disease reduction was found in Azoxystrobin 23\% SC (69.27\%) as compared to check with a projected yield of $6.91 \mathrm{t} / \mathrm{ha}$ which is significantly different from control. Among the other treatments good results were obtained by (Tebuconazole 50\%+ Trifloxystrobin 25\% WG) and Difenconazole $25 \%$ EC with 67.84 and $52.86 \%$ disease reduction, respectively with projected yield of 6.67 and 6.30 t/ha. Even the benefit cost ratio also follows the same trend i.e., highest for Azoxysrobin (1:0.89) though the fungicide is high cost as it is giving better results this can be recommended for the future purpose. The findings of Kumar et al., (2011) is corroborated with the outcome of the present study they also found Azoxystrobin as the most effective fungicide against Sheath blight (Table 1). 
Among the treatments, no significant difference was found in terms of AUCTPC and AUCTDC values. But significant differences have been found in case of AUSDC and AUDPC values. The lowest AUDPC value (191.20) was found in case of (Tebuconazole 50\% + Trifloxystrobin 25\% WG) followed by Azoxystrobin 23\% SC with AUDPC value of 202.22 which are significantly different from other treatments (Table 2).

Higher yield was obtained in case of Azoxystrobin 23\% SC which is significantly higher than control and the yield obtained by Tebuconazole $50 \%+$ Trifloxystrobin 25\% WG was found statistically at par with Azoxystrobin $23 \%$ SC. The fungicidal treatments are not having significant direct effect on the physiological traits but it is believed that they may have indirect effect on plant physiology by reducing the deterioration of chlorophyll by pathogen so that plant canopy can be kept at cooler temperature. But the fungicides showed significant effect on disease severity as well as yield of Rice.

\section{Bivariate analysis of physiological traits and AUDPC of treatment plots}

In the bivariate analysis, a positive correlation was found between AUDPC and AUCTPC this may be because Rhizoctonia is temperature loving pathogen. Whereas, the two other physiological traits, AUCTDC and AUSDC were found to be negatively correlated with AUDPC. As we know higher the chlorophyll content, cooler the micro climate of the canopy which ultimately limits the disease.

Table.1 Variation in the Percent Disease Index and B: C Ratio for different treatments

\begin{tabular}{|c|c|c|c|c|c|c|c|c|c|}
\hline \multirow[t]{2}{*}{ Treatments } & \multicolumn{5}{|c|}{ PDI } & \multirow{2}{*}{$\begin{array}{c}\text { Disease } \\
\text { reduction } \\
\%\end{array}$} & \multirow{2}{*}{$\begin{array}{l}\text { Plot } \\
\text { Yield } \\
\text { (Kg) }\end{array}$} & \multirow{2}{*}{$\begin{array}{c}\text { Projected } \\
\text { yield } \\
\text { (t/ha) }\end{array}$} & \multirow{2}{*}{$\begin{array}{l}\text { Benefit } \\
\text { Cost Ratio } \\
\text { (BCR) }\end{array}$} \\
\hline & $1^{\text {st }}$ & $2^{\text {nd }}$ & $3^{\mathrm{rd}}$ & $4^{\text {th }}$ & 5 th & & & & \\
\hline $\begin{array}{l}\text { Azoxystrobin } \\
23 \% \text { SC }\end{array}$ & $\begin{array}{l}6.66 \\
(2.67)^{*}\end{array}$ & $\begin{array}{l}8.88 \\
(3.05) \\
\end{array}$ & $\begin{array}{l}9.62 \\
(3.17)\end{array}$ & $\begin{array}{l}14.07 \\
(21.97) \\
\end{array}$ & $\begin{array}{l}15.93 \\
(23.48) \\
\end{array}$ & 69.27 & 4.15 & 6.91 & $1: 0.89$ \\
\hline $\begin{array}{l}\text { Difenconazole } \\
25 \% \text { EC }\end{array}$ & $\begin{array}{l}8.14 \\
(2.93)\end{array}$ & $\begin{array}{l}11.11 \\
(3.40)\end{array}$ & $\begin{array}{l}14.81 \\
(3.91)\end{array}$ & $\begin{array}{l}18.51 \\
(25.45)\end{array}$ & $\begin{array}{l}24.44 \\
(29.38)\end{array}$ & 52.86 & 3.78 & 6.30 & $1: 0.76$ \\
\hline $\begin{array}{l}\text { Validamycin } \\
3 \% \mathrm{~L}\end{array}$ & $\begin{array}{l}8.14 \\
(2.93) \\
\end{array}$ & $\begin{array}{l}11.11 \\
(3.40) \\
\end{array}$ & $\begin{array}{l}13.33 \\
(3.71) \\
\end{array}$ & $\begin{array}{l}22.96 \\
(28.62) \\
\end{array}$ & $\begin{array}{l}25.19 \\
(30.11) \\
\end{array}$ & 51.41 & 3.70 & 6.16 & $1: 0.77$ \\
\hline $\begin{array}{l}\text { Propiconazole } \\
25 \% \text { EC }\end{array}$ & $\begin{array}{l}12.59 \\
(3.61)\end{array}$ & $\begin{array}{l}13.33 \\
(3.71)\end{array}$ & $\begin{array}{l}17.77 \\
(4.26)\end{array}$ & $\begin{array}{l}23.70 \\
(28.82)\end{array}$ & $\begin{array}{l}28.89 \\
(32.48)\end{array}$ & 44.28 & 3.55 & 5.91 & $1: 0.70$ \\
\hline $\begin{array}{l}\text { Tebuconazole } \\
50 \%+ \\
\text { Trifloxystrobin } \\
25 \% \text { WG }\end{array}$ & $\begin{array}{l}7.96 \\
(2.90)\end{array}$ & $\begin{array}{l}6.66 \\
(2.65)\end{array}$ & $\begin{array}{l}8.88 \\
(3.05)\end{array}$ & $\begin{array}{l}15.55 \\
(23.19)\end{array}$ & $\begin{array}{l}16.67 \\
(24.06)\end{array}$ & 67.84 & 4.00 & 6.67 & $1: 0.88$ \\
\hline $\begin{array}{l}\text { Tebuconazole } \\
25 \% \text { EC }\end{array}$ & $\begin{array}{l}8.14 \\
(2.93) \\
\end{array}$ & $\begin{array}{l}11.85 \\
(3.50)\end{array}$ & $\begin{array}{l}13.33 \\
(3.71) \\
\end{array}$ & $\begin{array}{l}23.70 \\
(29.11) \\
\end{array}$ & $\begin{array}{l}34.07 \\
(35.70)\end{array}$ & 34.29 & 3.59 & 5.98 & $1: 0.71$ \\
\hline $\begin{array}{l}\text { Hexaconazole } \\
5 \% \mathrm{SC}\end{array}$ & $\begin{array}{l}7.40 \\
(2.80) \\
\end{array}$ & $\begin{array}{l}9.62 \\
(3.17) \\
\end{array}$ & $\begin{array}{l}13.33 \\
(3.69) \\
\end{array}$ & $\begin{array}{l}16.29 \\
(23.65) \\
\end{array}$ & $\begin{array}{l}26.67 \\
(31.05) \\
\end{array}$ & 48.56 & 3.78 & 6.31 & $1: 0.82$ \\
\hline Control & $\begin{array}{l}11.11 \\
(3.40)\end{array}$ & $\begin{array}{l}16.29 \\
(4.09)\end{array}$ & $\begin{array}{l}20.00 \\
(4.52)\end{array}$ & $\begin{array}{l}27.40 \\
(31.50)\end{array}$ & $\begin{array}{l}51.85 \\
(46.08)\end{array}$ & - & 3.42 & 5.70 & $1: 0.67$ \\
\hline CV \% & 6.453 & 9.993 & 8.638 & 11.769 & 12.341 & - & 8.520 & - & \\
\hline CD & 0.342 & 0.590 & 0.568 & 5.4709 & 6.818 & - & 0.559 & - & \\
\hline SEm \pm & 0.1128 & 0.1946 & 0.1873 & 1.8037 & 2.2477 & - & $\begin{array}{l}0.184 \\
4\end{array}$ & - & \\
\hline
\end{tabular}

Data within the parentheses are angular and Arc Sin transformed values 
Table.2 Relation various traits and yield for treatment plots

\begin{tabular}{|c|c|c|c|c|c|}
\hline Treatment & AUCTPC & AUCTDC & AUSDC & AUDPC & Yield \\
\hline (Azoxystrobin $23 \% \mathrm{SC}$ ) & $574.82^{\mathrm{A}}$ & $205.80^{\mathrm{A}}$ & $816.62^{\mathrm{A}}$ & $202.22^{\mathrm{D}}$ & $4.15^{\mathrm{A}}$ \\
\hline (Difenconazole 25\% EC) & $586.37^{\mathrm{A}}$ & $186.32^{\mathrm{A}}$ & $778.26^{\mathrm{ABC}}$ & $274.82^{\mathrm{C}}$ & $3.78^{\mathrm{ABC}}$ \\
\hline (Validamycin 3\% L) & $601.37^{\mathrm{A}}$ & $179.25^{\mathrm{A}}$ & $770.44^{\mathrm{ABC}}$ & $279.99^{\mathrm{BC}}$ & $3.70^{\mathrm{ABC}}$ \\
\hline (Propiconazole $25 \%$ EC) & $587.30^{\mathrm{A}}$ & $177.45^{\mathrm{A}}$ & $746.78^{\mathrm{CD}}$ & $344.81^{\mathrm{AB}}$ & $3.55^{\mathrm{BC}}$ \\
\hline $\begin{array}{l}\text { (Tebuconazole } \\
50 \%+\text { Trifloxystrobin } 25 \% \mathrm{WG})\end{array}$ & $576.22^{\mathrm{A}}$ & $204.40^{\mathrm{A}}$ & $799.63^{\mathrm{AB}}$ & $191.20^{\mathrm{D}}$ & $4.00^{\mathrm{AB}}$ \\
\hline (Tebuconazole 25\% EC) & $596.05^{\mathrm{A}}$ & $184.57^{\mathrm{A}}$ & $760.43^{\mathrm{BC}}$ & $287.78^{\mathrm{BC}}$ & $3.59^{\mathrm{BC}}$ \\
\hline (Hexaconazole 5\%SC) & $588.70^{\mathrm{A}}$ & $191.92^{\mathrm{A}}$ & $778.14^{\mathrm{ABC}}$ & $243.70^{\mathrm{CD}}$ & $3.79^{\mathrm{ABC}}$ \\
\hline Control & $613.20^{\mathrm{A}}$ & $167.42^{\mathrm{A}}$ & $705.49^{\mathrm{D}}$ & $388.89^{\mathrm{A}}$ & $3.42^{\mathrm{C}}$ \\
\hline$\alpha=0.050 \mathrm{t}=2.14479$ & NS & NS & $\mathbf{S}$ & $\mathbf{S}$ & $\mathbf{S}$ \\
\hline $\mathrm{CD}_{(0.05)}$ & 43.56 & 49.68 & 40.58 & 0.55 & 0.56 \\
\hline
\end{tabular}

NS - Non Significant; S - Significant

Table.3 Relation between area under disease progress curve and yield

\begin{tabular}{|l|l|l|l|l|}
\hline Treatment & AUDPC & Yield & \% Reduction in AUDPC & \% Increase in yield \\
\hline T1 & 892.22 & 4.15 & $48.00^{\mathrm{AB}}$ & $21.44^{\mathrm{A}}$ \\
\hline T2 & 1510.00 & 3.78 & $29.33^{\mathrm{CD}}$ & $10.53^{\mathrm{B}}$ \\
\hline T3 & 1603.33 & 3.70 & $28.00^{\mathrm{CD}}$ & $8.19^{\mathrm{B}}$ \\
\hline T4 & 1673.70 & 3.55 & $19.90^{\mathrm{D}}$ & $12.48^{\mathrm{AB}}$ \\
\hline T5 & 932.31 & 4.01 & $50.83^{\mathrm{A}}$ & $17.15^{\mathrm{AB}}$ \\
\hline T6 & 1616.67 & 3.59 & $26.00^{\mathrm{CD}}$ & $7.60^{\mathrm{B}}$ \\
\hline T7 & 1231.85 & 3.79 & $37.33^{\mathrm{BC}}$ & $10.72^{\mathrm{AB}}$ \\
\hline Control & 2211.85 & 3.42 & 0.00 & 0.00 \\
\hline
\end{tabular}

Fungicides used for field evaluation

\section{S. No Fungicide}

$\mathrm{F}_{1}$. Azoxystrobin 23\%SC (Amistar)

$\mathrm{F}_{2}$. Difenconazole 25\% (Score)

$\mathrm{F}_{3} . \quad$ Validamycin 3\% (Sheathmar)

$\mathrm{F}_{4}$. Propiconazole $25 \%$ (Tilt)

F. $\quad$ Tebuconazole 25\% EC (Folicure)

$\mathrm{F}_{6} . \quad$ Tebuconazole 50\%+Trifloxystrobin $25 \%$ WG (Nativo)

$\mathrm{F}_{7}$. Hexaconazole 5\% SC (Contaf)
Concentrations

$10,20,40,80$ and $160 \mathrm{ppm}$

$10,20,40,80$ and $160 \mathrm{ppm}$

$10,20,40,80$ and $160 \mathrm{ppm}$

$10,20,40,80$ and $160 \mathrm{ppm}$

$10,20,40,80$ and $160 \mathrm{ppm}$

$0.5,1.0,2.0,4.0$ and $8 \mathrm{ppm}$

$0.5,1.0,2.0,4.0$ and $8 \mathrm{ppm}$
Dose

$1 \mathrm{ml} / \mathrm{L}$

$1 \mathrm{ml} / \mathrm{L}$

$2 \mathrm{ml} / \mathrm{L}$

$1 \mathrm{ml} / \mathrm{L}$

$1 \mathrm{ml} / \mathrm{L}$

$0.5 \mathrm{~g} / \mathrm{L}$

$2 \mathrm{ml} / \mathrm{L}$
Relation between physiological traits, AUDPC with yield

A positive correlation has been found in between the yield and AUCTDC, AUSDC. Simultaneously a negative correlation found in between AUCTPC, AUDPC and yield.
Here, in first case, if the plant maintains chlorophyll for some period it's temperature depression will be more so that disease effect will be minimized to get higher yield. In the second case, higher canopy temperature favours the disease which results into the yield loss. 
Yield loss assessment by using AUDPC model

A positive quantitative correlation was found in between percent reduction in AUDPC and percent increase in yield of rice. This implies that reduced disease severity results in increased yield of rice vice-versa. As shown in Table 3 the maximum \% reduction in disease was observed in T1 (Azoxystrobin $23 \% \mathrm{SC}$ ) where the maximum $\%$ increase in yield also observed.

Simultaneously the maximum yield reduction was observed in control where maximum disease also observed. This increase in yield is the result of retention of high chlorophyll till the harvest and balancing the canopy temperature with environment temperature to stop the disease outbreak. Triazoles can be used as a promising chemical control tool for rice sheath blight management as the treatment T1 (Azoxystrobin23\%SC) has given the maximum $\mathrm{BC}$ ratio (1:0.89) with highest \% disease reduction (48) and highest projected yield (6.91) with lowest AUCTPC (574.82) and highest AUSDC (202.22).

This clearly indicates that the chemicals will help in reduction of the inoculum load, also help the plant to maintain high chlorophyll content and optimum canopy temperature which will not favour the spread of fungus. Though fungicides leave a chemical foot print, new fungicides with novel action help in managing the diseases without hampering the ecological balance. These chemicals does not act directly on pathogen, they choose indirect ways either through plant or may be pathogen metabolism to protect plant from diseases.

\section{Acknowledgement}

Uttar Banga Krishi Viswavidyala, Department of Plant Pathology

\section{Author contributions}

All authors equally contributed

\section{Abbreviations}

AUDPC - Area Under Disease Progress Curve

AUSDC - Area Under Spad Decline Curve

AUCTDC - Area Under Canopy Temperature Decline Curve

AUCTPC - Area Under Canopy Temperature Progress Curve

BCR - Benefit Cost Ratio

\section{Ethical approval}

This article does not contain any studies with human participants or animals performed by any of the authors.

\section{References}

Anonymous. 1996. Standard evaluation system of rice. IRRI. Manila. Philippines. pp-25.

Castro C, Davis JR, Wiese MV. 1988. Quantitative estimation of Rhizoctoniasolani AG-3 in soil. Phyto.pathol. 78:1287-1292.

Gangopadhyay S, Chakrabarti NK.1982. Sheath blight of rice. Rev. Plant Pathol. 61:451-460.

Ko W, Hora FK. 1971. A selective medium for the quantitative determination of Rhizoctonia solani in soil. Phyto.pathol. 61:707-710.

Kumar KVK, Yellareddygari SKR, Reddy MS, Kloepper JW, Sudini H, Zhou XG, Reddy ECS, ZhiLinY, ZhiLing Y, QiWang Hai DB, Reddy BR, Reddy BVB, Reddy MS, Wang QIY, Zhang L, Du B, Yellareddygari SKR. 2011. Evaluation 
of combined efficacy of Bacillus subtilis MBI 600 and Azoxystrobin in managing rice sheath blight caused by Rhizoctonia solani. Proceedings of the 2nd Asian PGPR Conference. 270280.

Ou S K. 1985. Rice diseases. CMI, Kew, Surrey, England. 380 pp.

Rajan CPD. 1987. Estimation of yield losses due to sheath blight of rice. Indian Phyto pathol. 40: 174-177.

Riker A.J., Riker R.S. 1936. Introduction of Research on Plant Disease.John Swift Co., St. Lousi, 117 pp.

Rosyara UR, Khadka K, Subedi S, Sharma RC and Duveiller E. 2009. Field resistance to spot blotch in three spring wheat populations. J Pl Pathol. 91(1): 113-122.

Rosyara UR, Pant K, Duveiller E and Sharma R.C. 2007. Variation in chlorophyll content, is not associated with undesirable physio morphological traits spot blotch resistance under natural epiphytotic conditions. Australian $\mathrm{Pl}$ Pathol. 36: 245- 246

Roy AK. 1993. Sheath blight of rice in India. Indian Phyto pathol. 46 : 97-205.

Shaner G, Finney R. 1975. Inheritance of slow mildewing resistance in wheat. Proc. Am. Phytopathol. Soc. 2:49 (Abstr.).

Wheeler B E J. 1969. An introduction to plant disease. John Willy and sons Ltd. London. Pp.301.

\section{How to cite this article:}

Ashajyothi Mushineni, Surajit Khalko, Susmita Jha, P.M. Bhattacharya and Ayon Roy. 2017. Effect of New Generation Chemicals in Changing Host Physiological Traits to Manage Sheath Blight Disease Caused by Rhizoctonia solani Kuhn in Rice. Int.J.Curr.Microbiol.App.Sci. 6(11): 351-357. doi: https://doi.org/10.20546/ijcmas.2017.611.039 